\title{
The Influence of Language Development on EFL Teachers in Classroom Practice
}

\begin{abstract}
Sitti Fatimah
Abstrak: Artikel ini membahas pengaruh perkembangan bahasa terhadap teknik mengajar guru bahasa Inggris. Artikel ini karenanya dibagi atas dua pembahasan utama. Yang pertama membahas tentang teori perkembangan bahasa baik L1 maupun L2. Sedangkan pembahasan yang kedua tentang teknik yang dapat digunakan guru sehubungan dengan pemahaman mereka tentang perkembangan bahasa siswa.
\end{abstract}

Kata kunci: language development, language influence, teachers' classroom practices

\section{INTRODUCTION}

Until the time this article is written, language - both spoken and written - is still widely used as the main tool of communication for human beings regardless the age, time and place where they live; although it is often accompanied by other forms, such as gestures and facial expressions. As long as people are alive and keep engaging with others, they will always use a language. Even, a baby in its mother's tummy has begun its first communication when the mother talks to it while softly rubbing her stomach. Quite frequently, a dying person still tries hard to say something to someone $\mathrm{s} / \mathrm{he}$ is going to leave.

Then, people recognize that the large majority of them are surrounded by either bilingual or multilingual speakers. This happens, of course, because there is hardly a place where there are only homogenous people reside. In other words, it is almost impossible to identify such a community in this world since there is always a mixture of society comprising more than one culture in almost every part of the world. But to name few of them from very rare groups are perhaps some aboriginal people in Australia who still isolate themselves from outer world and the exclusive and primitive Azmat tribe living in a remote place of Irian jungle in Indonesia. These people are likely to recognize and speak only one language; by this they are named monolingual speakers.

Since there are a huge amount of human languages existing in all over the world, there has been a major classification of them into two large groups: first language (L1) and second language (L2). L1 refers to the native language or 'mother tongue', whereas L2 means any "languages other than mother tongue (Mitchell \& Myles, 2001, p. 11)". Almost all people successfully acquire L1 at their early years which occurs naturally (Emmit \& Pollock, 1997, p. 158), but only some of them who can achieve L2 or both L1 and L2 naturally and simultaneously in their bringing up time. Many people have to attend institutionally run L2 learning in order to accomplish it. Before people come to a stage where they proficiently achieve L1 or L2, they definitely go through the process of developing it. Regarding the language progress, this article will mainly discuss the process of the first and second language acquisition and development and how they can affect EFL (English as a Foreign Language) teachers in their classroom practice.

\section{FIRST LANGUAGE (L1) ACQUISITION AND DEVELOPMENT}

It has been previously mentioned that $\mathrm{L} 1$ is naturally achieved at the early stages of human's life. What a child really learns about the language is highlighted by Emmit \& Pollock (1997, p. 161) who state that at this time, they (the children) "do not only learn the system of speech, such as patterns of sound, words and sentences, but as a whole they learn to a system for making and sharing meaning." It can be said that the process of L1 acquisition is usually perfectly completed without passing through formal learning. 
To completely know how children acquire their mother tongue, there has been a great deal of respective research conducted since a very long time ago. Thus, some theories have been resulted based on the research. The first one is behaviourism theory proposed by Skinner who was inspired by Ivan Pavlov's experiments on animals from which he concluded that "learning process occurs because there is habitual response to certain stimulation (cited in Emmit \& Pollock, 1997, p. 162)." From Pavlov's conclusion, Skinner (1957, pp. 1-2) claimed that language functions as verbal behaviour. What he meant by this is that the communication realized between speakers and listeners is the result of verbal behaviour after interacting with environment and passing through thinking process. Therefore, Skinner also concluded "Man Thinking is simply Man Behaving" (p. 452).

Then, behaviourism theory is analyzed into three principles, as Fromkin, Blair and Collins (1999, p. 327) mention, they are imitation, reinforced and analogy. By imitation they say that usually children imitate what adults tell them but also exemplify some data describing children do not always successfully imitate adult's words. The second theory they explain is that children learn to produce correct (grammatical) sentences because they are positively supported when they say something right and negatively when they say something wrong. Then, the repetition of associations is often used by children to acquire their language.

In contrast with Skinner's idea, Chomsky (cited in Emmit \& Pollock, 1997, p. 164) did not think that "language should be thought of as verbal behaviour, but of as knowledge held by those who use the language". This idea is recognized as cognitive view of language learning. About one decade later, Halliday (1975, p. 60) proposed another somewhat contrary principle of language development. He made a synthesis of three moods of interpretation:

1. Language in the context of the social system

2. Language as an aspect of a more general semiotic

3. Language as the social system itself as semiotic system

Halliday highlighted that when "language functions as the expression of the social semiotic, simultaneously it has a role as the means of transmitting it and also constantly modifying and reshaping it, as the child takes over the culture (the received system of meanings) where he is learning to interact." By this thought language is also known as interaction.

While these theories of first language acquisition continue to be reviewed and sometimes becoming the starting points of new ones, still it seems that there is no single theory subscribed in respect to first language research.

\section{SECOND LANGUAGE (L2) ACQUISITION AND DEVELOPMENT}

Unlike L1 accomplishment that is normally acquired through natural and automatic process, acquiring L2 mostly involves and requires some processes of formal classroom learning. In addition, as Mitchell and Myles note $(2001$, p. 16), the environmental circumstances for L2 learning is systematically different from L1 learning. In the contrary, however, Emmit and Pollock (1997, p. 186) see some resemblances between these two. They say, to some extent, there are similarities between the first and second language in their acquisition, such as captivation in the language, hearing and seeing the language in purposeful contexts, opportunity to use the language and to receive feedback. So, it should not be interpreted that the process of acquiring second language is systematically taken away from the principles of the first one.

As for the theory of SLA, Brown (2000, p. 271.) assures that "there is not really an integrated, unified theory or a standard set of constructs to which large numbers of researchers and teachers primarily subscribe." However, from a large number of current generalizations, hypotheses, and models of SLA, Brown (2000, p. 277-280) summarized Krashen's hypotheses into five:

\section{The Acquisition-Learning Hypothesis}

This theory believes that SLL have two means to internalize the target language: a subconscious and intuitive process of constructing the system of a language and conscious learning process in which learners deal with form, figure out rules and are generally aware of their own process.

\section{The Monitor Hypothesis}

In the process of teaching a language, teachers have a function; one of the others, to 
The Influence of Language Development on EFL Teachers in Classroom Practice (Sitti Fatimah)

monitor learners' output whether to make alterations or corrections if they find them.

\section{The Natural Order Hypothesis}

The process of acquiring a second language rules is conducted in predictable or natural order.

\section{The Input Hypothesis}

The input given to second language learners should not be either too easy so that it cannot challenge them, or too difficult so that it can make them confused. Rather, it should be slightly beyond their current knowledge or ability.

\section{The Affective Filter Hypothesis}

In this last hypothesis, it is believed that the context where best acquisition occurs is the environment in which the anxiety is low and defensiveness is absent.

Unfortunately, these hypotheses seem to not be broadly referred as effective and valid theories to help promoting second language learning. Therefore, in this article their implication in classroom practice is not going to be discussed. But some factors affecting the process of second language acquisition will be essentially reviewed. Despite arguable results derived from many longconducted studies and experiments because, for instance, there is not always a positive correlation between motivation owned by a learner and his/her achievement in second language, it seems that many language researchers believe that there is always valid outcome in each research that has given some truthful evidence so that language teachers may refer to these results to improve their teaching strategies. The factors that are often mentioned are, as quoted from Larsen-Freeman and Long (1991, pp. 153-219), age, aptitude, motivation, attitude, personality, cognitive style, and learning strategies. But in this occasion only four factors to be discussed, i.e. age, aptitude, motivation and personality.

By knowing the theories of language development previously mentioned and affecting factors on the successfulness of language learning, language teachers especially EFL teachers are expected to invent accommodating teaching strategies and techniques in classroom practice. So, at the following paragraphs the discussion will be focused on how to apply those theories of language development in teaching language, especially English as a foreign language.

\section{THE INFLUENCE OF LANGUAGE DEVELOPMENT ON EFL TEACHERS IN CLASSROOM PRACTICE}

After recognizing and fully comprehending the process of first language acquisition and second language learning, EFL teachers then should be able to reflect their knowledge and understanding to their teaching context which covers some elements, such as, material selection, lesson planning, syllabus design, classroom management and teaching method. In other words, their understanding about the theory of language acquisition and development should be able to help them prepare and arrange those teaching elements in an attempt to achieve successful language learning.

Despite the controversy of applying the premise of behaviorism theory in language learning, its possible advantageous application of especially imitation theory still can be seen. If EFL teachers can grasp the idea of imitation theory, they can include audiolingual method in teaching L2 pronunciation, especially to adults. Adult learners very frequently find difficulty to produce correct pronunciation specifically to the sound that is very much different from their L1. For example, the word like 'rough' or 'mouse' is often incorrectly pronounced by Indonesian learners. Sometimes, to train pronouncing the sound $/ \mathrm{sh} /$ as in 'she' or 'wash' and the sound /th/ as in 'think' or 'bath' can take much time. This is because the difference of pronouncing a word between Indonesian and English. In Indonesian language all words are always pronounced as they are written. The activity that can be used by teachers can be drill exercises as one of choices, like asking learners to repeat a difficult word after being pronounced. However, teacher should be very attentive and cautious. When they see learners start to get bored with this exercise, teachers should be able to quickly switch to another activity although the time allocated is still available. Even though this activity looks oldfashioned technique, once in while it can be used as a useful alternative.

As for young learners, imitation theory is not really bad implementing. It is a matter of the technique of presenting it. If EFL teachers are 
creative to invent interesting ways, this theory can result in fruitful outcome. Through pictures, games and song, it is believed that children will have fun to imitate the sound of words. This is because, unlike adults who sometimes need some push, children are very quick at imitating.

Another activity applying behaviourism theory in teaching reading to young learners is described by Emmit and Pollock (1997, p. 163). This activity is fully based on the assumption that "learning to read is thought of as matching the correct verbal response to the appropriate visual stimulus: saying the right word when the word is shown." The procedure is words and single alphabetic letters are printed on cards and are rapidly displayed or flashed at children to establish the association between the stimulus of the flashed card and the response which is either the word is called out loud by children or the supposed sound that the alphabetic letter is meant to represent. Clearly, the choice of this activity is only suitable for children.

The understanding of the theory of interaction where language functions as social semiotic is also quite useful to be implemented in EFL classroom. What underlies this theory is that language is widely used by human beings for communicating in any forms and any places. I view that this theory thoroughly and broadly covers all human's activities that use language. In classroom practice it is especially important to be implemented. Viewing that communicative methodology in language teaching is very popular and to some extent has been proven quite successful to produce competent learners; I think interaction theory is very appropriate to be used in teaching language. In my experience, almost all of language classroom activities require students' interaction both with teacher and classmates. The only language skill that only involves little interaction especially with fellow students is listening lesson. This is definitely because learners mostly deal with the recording from audio/video player. However, at discussion or question-answer session usually held after listening to or watching the tape or cassette, active interaction can occurs. Thus, in the following paragraphs some possible interactive activities are exemplified for EFL teachers to perform.

For speaking lesson, role-play is one of good ideas. Teacher may give a prescribed situation to be acted out or s/he can only give a topic or even give freedom to learners to choose their topic and create their own lines. This activity can be carried out in pairs or in groups depending on the topic chosen. By doing this task, students learn to build cooperation, to learn to listen to other's ideas in choosing the topic and to construct togetherness in enacting the piece of play. Other positive outcome is, of course, students can practice and then produce correct pronunciation. In addition, it may train students to be self-esteem because there is a chance to positively change inhibited learners to be more self-expressive in terms of sharing ideas or asking question.

In assigning reading task, teacher can also have some alternatives for activities involving students to have interaction. For example, in jigsaw reading activity where students can be grouped, they will automatically work together. A spirit of working together can also be encouraged in scanning reading. Instead of giving a text followed by and a number of questions to individual learners, teacher can invent another alternative. He may arrange the learners to work in groups and to make it fun the reading text is not distributed but sticked to the wall. So, one or two members have to go to the text and read it and then return to their seat where their friend is sitting holding the list of questions and write the answers based on the reading of other member. The type of reading text should be varied. Besides giving scientific texts, a once-in-a-while entertaining text can refresh students' mind.

Then, the following paragraphs are discussions of what language teachers can do to improve their teaching techniques after getting the knowledge of factors affecting SLA.

\section{Age}

From a large amount of the research conducted to discover whether a learner's age has an effect on his/her L2 achievement, there is a conclusion informing that children studying SLA will immediately acquire native-like proficiency, but is slow at mastering syntactic features. On the contrary, adult learners will be unlikely acquire native-like pronunciation but is good at other language components. Based on these research findings, teachers' strategies in classroom can be modified in order to adjust them to the need of certain age; for instance, adults are given a large 
portion of pronunciation and speaking practice. Meanwhile, young learners can be focused on the skill of reading, vocabulary and grammatical sentences through fun activities like games, roleplay and songs.

\section{Aptitude}

To accommodate the learners with special aptitude, Lightbown and Spada (2001, p. 32) suggest an appropriate teaching program suited to their strength and weaknesses in components of aptitude. For instance, as conducted in a Canadian language program for adult learners of French, students who were good at analytic ability but average on memory were put in the class focusing on grammatical structures.

\section{Motivation}

The results of studies have revealed that motivation refers to the interest owned by learners. Basically, when learners are interested in a lesson, they will be motivated to learn it. To make a lesson interesting, language teachers should take some actions. They can as often as possible make variations of reading text given in reading class. Another alternative is changing class arrangement: working individually, in pairs, and in groups. Making variations of activities, such as games, songs, role-play in speaking class is believed to increase learners' interest. So, principally to get learners' interest is to kill their boredom.

\section{Personality}

Each learner has different personality. There is one who is very talkative, but on the contrary there is a learner who is very quiet. There are also students whose personality in between these traits or who are in the average: not too aggressive and not too silent. Then, every language teacher is supposed to recognize each learner's characteristic and find any techniques to cope with it so that none of them is neglected or over poured with attention.

In classroom activity, inhibited learner's mistake should not be directly corrected because he or she may be ashamed and then it may discourage them to be active. On the other hand, self-confident learners should not be always let to talk especially in class (panel) discussion as they can dominate the class.

\section{CONCLUSION}

Understanding the process of language development is very significant for language teachers especially EFL teachers. This is because they can get much benefit to improve their teaching strategies and techniques which lead to the improvement of learning outcome. However, in some EFL countries like Indonesia, access to latest research results is not very feasible because of lack of facility. Overseas published and printed books are unreachable by teacher's salary. Additionally, most teachers have no internet access at home to view current information. So, it is unsurprising when most teachers are still using the same old theory which is frequently proven ineffective.

\section{REFERENCES:}

Brown, H. D. 2000. Principles of language learning and teaching ( $4^{\text {th }}$ Ed.). New York: Longman

Emmit, M. \& Pollock, J. 1997. Language learning: An introduction for teaching. Oxford: Oxford University Press.

Fromkin, V., Blair, D. \& Collins, P. 1999. An introduction to language. Victoria: Thomson

Halliday, M. A. K. 1975. Learning how to mean: Explorations in the development of language. London: Edward Arnold.

Larsen-Freeman, D. and Long, M. H. 1991. An introduction to second language acquisition research. London: Longman.

Lightbown, P. M. \& Spada, N. 2001. Factors affecting second language learning. In C. N. Candlin and N. Mercer (Eds.), English language teaching in its social context: A reader (28-43). London; New York: Routledge.

Mitchell. R. \& Myles, F. 2001. Second language learning: Key concepts and issues. In C. N. Candlin and N. Mercer (Eds.), English language teaching in its social context: A reader (11-27). London; New York: Routledge.

Skinner, B. F. 1957. Verbal behaviour. New York: Appleton-Century-Crofts, Inc. 